\title{
Antibacterial properties of propolis and products containing propolis from Brazil
}

\author{
H Menezes*, M Bacci Jr, SD Oliveira, FC Pagnocca \\ Centro de Estudos de Insetos Sociais, Instituto de Biociências, \\ Unesp, Rio Claro, São Paulo, Brazil
}

(Received 21 August 1996; accepted 10 March 1997)

\begin{abstract}
Summary - Crude propolis and commercial products containing propolis, such as ethanolic extracts, tablets, capsules and powders acquired in São Paulo City (Brazil) were analyzed. The resins of the solid products were extracted with ethanol and found to be present at various concentrations, independently of the propolis concentration specified on the label of the commercial products. The in vitro activity of these resins against $S$ aureus, $B$ cereus and $B$ subtilis was also determined. The results showed that the antibacterial activity rather than the propolis concentration itself should be considered for quality control and that some resins are likely to display a species-specific action.
\end{abstract}

propolis / resin / Apis mellifera / quality control / antibacterial activity / Staphylococcus aureus / Bacillus cereus / Bacillus subtilis

\section{INTRODUCTION}

Propolis (bee glue) has been used in folk medicine for centuries (Ghisalberti, 1979). This is supported by recent findings about its biological properties such as antibacterial (Grange and Davey, 1990), antiviral (Amoros et al, 1992) or anti-protozoan (Starzyk et al, 1977) activity, inhibition of tumor processes (Frenkel et al, 1993), antiinflammatory action (Dobowolski et al, 1991; Volpert and Elstner, 1996), induction of both bone (Stojko et al, 1979) and cartilaginous tissue regeneration (Scheller et al, 1977), free radical scavenging (Scheller et al, 1989; Volpert and Elstner, 1993), and allergenic effect (Hausen et al, 1987a, b; Ginanneschi et al, 1989). The biological properties and chemical composition of propolis have been recently reviewed (Marcucci, 1995).

The characterization of these biological properties together with the current trend towards utilizing natural products have resulted in an increased demand for propo-

* Corresponding author: IB-Unesp, av 24 "A" n 1515, PO Box 199, Rio Claro, SP, Brazil, CEP: 13506-900.

Fax: (55) 195340009. 
lis and products containing propolis, such as ethanol extracts, tablets, capsules, sprays, or powders.

The expansion of the propolis industry requires standardization of these products, and should take into account regional vegetation diversity (Vanhaelen and Vanhaelen-Fastré, 1979), the harvesting activity of distinct races of honeybees (Singh, 1972), and establish the efficacy of the products. In addition, such a standardization needs to be simple and inexpensive to be accessible to manufacturers.

In this context, the objective of the present study was the evaluation of the in vitro antibacterial activity of the different formulations of propolis. Samples were bought in pharmacies, drugstores and from beekeepers.

\section{MATERIALS AND METHODS}

\section{Propolis and commercial products containing propolis}

Three groups of products were studied in this work: ten different commercial ethanolic extracts referred to as CE1 to CE10; commercial preparations of tablets, capsules and powders containing propolis; two other ethanolic extracts prepared in our laboratory using crude propolis from one site reforested with Pinus sp and another reforested with Eucalyptus sp. All these propolis samples were from $A$ mellifera and the extracts were prepared with $95 \%$ pa ethanol (Merck).

\section{Determination of resin concentration in commercial alcoholic extracts}

Aliquots of $5.0 \mathrm{~mL}$ of each extract were transferred to previously weighted flasks and evaporated at $50^{\circ} \mathrm{C}$ until constant weight was reached.

\section{Determination of resin content in crude propolis and in solid commercial product}

One hundred grams of crude propolis of Pinus sp or Eucalyptus sp were mixed with $200 \mathrm{~mL}$ of $95 \%$ ethanol and maintained in a rotatory water bath shaker during 1 week at $25^{\circ} \mathrm{C}$. The ethanolic extracts were then filtered in Whatmann no 1 filter paper and designated as E-Pinus or E-Eucalyptus. The resin extraction procedure for the solid commercial products was similar but using $200 \mathrm{~g}$ of every product $/ 200 \mathrm{~mL}$ of ethanol. These extracts were designated as E-tablet, E-capsule and E-powder. The resin content of these five extracts was determinated by the same procedure as that used with the commercial alcoholic extract. After determinating the resin content, all 15 samples were diluted with $95 \%$ ethanol to $10 \mathrm{mg} / \mathrm{mL}$ (stock-solution) which was used for the antibacterial activity assay. The resin content (\% resin) was expressed in grams of resin per $100 \mathrm{~mL}$.

\section{Antibacterial activity determination}

This determination was adapted from Waksman and Reilly (1945). The propolis sensitive bacteria (Grange and Davey, 1990) Staphylococcus aureus ATCC 6538, Bacillus cereus CCT 1436, and Bacillus subtilis CCT 2471 were cultivated $\left(24 \mathrm{~h}, 35^{\circ} \mathrm{C}\right.$ ) on Nutrient Agar medium (Difco) and then suspended (one unit on the MacFarland scale) in sterile saline $0.85 \%$. The suspensions $(0,1 \mathrm{~mL})$ were sprayed with a cotton swab onto the surface of solid media in Petri dishes. The culture medium had been previously prepared by mixing $9.0 \mathrm{~mL}$ of melted $\left(47^{\circ} \mathrm{C}\right) \mathrm{NA}$ medium with $1 \mathrm{~mL}$ of $95 \%$ ethanol (control) or with $1 \mathrm{~mL}$ of dilutions of resin stock solutions. The results were expressed in 'limit concentration' (LC), ie, the minimum concentration of resin $(\mu \mathrm{g}$ of resin per $\mathrm{mL}$ of culture medium) which completely inhibited bacterial growth. The LC values represented the average of at least two assays.

\section{RESULTS}

Table I shows the propolis concentration specified on the label of the commercial products by manufacturers, and the resin concentration of these products determined in the present investigation. The ethanolic extracts from Pinus (E-Pinus) or Eucalyptus (E-Eucalyptus) crude propolis, prepared to contain $33 \%(\mathrm{w} / \mathrm{v})$ of propolis were found to contain resin at $13.4 \%$ and $12.8 \%$, respec- 
tively. Similar analysis showed that commercial products contained a minimum of 1.5 to 14.2 maximum of \% (w/v) resin.

Results of antibacterial activity of the different resins (table II) showed that $B$ cereus was always the most sensitive organism, followed by $B$ subtilis, and $S$ aureus. The LC values obtained with these organisms characterized the low activity of CE10, tablet, capsule and powder resins when compared to the higher activity of resins from CE1, CE7, and E-Eucalyptus and E-Pinus. In addition, resins from capsuled and powdered propolis were effective against $B$ cereus, but presented low activity against $B$ subtilis and $S$ aureus.

\section{DISCUSSION}

The products analyzed in the current investigation showed different resin concentra- tions (table I), regardless of the propolis concentration specified on their labels. This finding probably reflects variable crude propolis composition including wax, wood fragments, debris, and water (Ackermann, 1991).

The results of antibacterial activity showed differences in the quality of the resins investigated. For instance, CE10 was found to have a high resin content $(12.3 \mathrm{~g} \%)$ (table I), but presented a high LC value for all microorganisms tested (table II). Other evidence showing that resin source and probably their composition can, at least for antibacterial purposes, be more important than the concentration itself, was obtained from the comparison of LC from E-Eucalyptus and E-Pinus. The antibacterial activity against $S$ aureus and $B$ subtilis of $E$ Eucalyptus was sligthly higher than E-Pinus. Since the only difference between them is the plant species, we think that the

Table I. Propolis and resin concentration of analysed products.

\begin{tabular}{lcc}
\hline Sample & $\begin{array}{c}\text { Propolis }(\%) \\
\text { specified by manufacturer }\end{array}$ & $\begin{array}{c}\text { Original resin } \\
\text { concentration }(\%)\end{array}$ \\
\hline E-Pinus & $33^{*}$ & 13.4 \\
E-Eucalyptus & $33^{*}$ & 12.8 \\
CE1 & 33 & 14.2 \\
CE2 & 40 & 12.2 \\
CE3 & 10 & 3.3 \\
CE4 & 20 & 4.4 \\
CE5 & 15 & 4.9 \\
CE6 & 20 & 6.5 \\
CE7 & 25 & 8.2 \\
CE8 & 15 & 4.3 \\
CE9 & 30 & 9.8 \\
CE10 & 20 & 12.3 \\
E-Tablet & NS & 1.5 \\
E-Capsule & NS & 8.2 \\
E-Powder & NS & 7.7 \\
\hline
\end{tabular}

E: ethanolic extract; CE: commercial ethanolic extract; NS: propolis concentrations not specified by the manufacturer; *: prepared in our laboratory. 
Table II. Limit concentration (LC), in $\mu \mathrm{g} / \mathrm{mL}^{-1}$, of resins extracted from propolis or propolis-containing commercial products.

\begin{tabular}{lccc}
\hline Sample & S aureus & B cereus & B subtilis \\
\hline E-Pinus & & & \\
E-Eucalyptus & 100 & 50 & 90 \\
CE1 & 80 & 50 & 80 \\
CE2 & 80 & 30 & 70 \\
CE3 & 100 & 50 & 80 \\
CE4 & 100 & 40 & 70 \\
CE5 & 100 & 60 & 80 \\
CE6 & 130 & 60 & 100 \\
CE7 & 100 & 40 & 70 \\
CE8 & 80 & 30 & 50 \\
CE9 & 150 & 50 & 110 \\
CE10 & 100 & 30 & 60 \\
E-Tablet & 600 & 200 & 500 \\
E-Capsule & 700 & 200 & 500 \\
E-Powder & 200 & 50 & 140 \\
\hline
\end{tabular}

E: ethanolic extract; CE: commercial ethanolic extract.

different chemical composition of their resin is responsible for the observed effects. Some Eucalyptus species are known for the antibacterial activity of some compounds in their essential oils (Haiji and FkihTetouani, 1993). In addition, inadequate storage could also result in a propolis with high resin content, but low antibacterial activity.

Inactivation of antibacterial compounds during the manufacturing process and utilization of low quality propolis are some of the possible reasons for the low antibacterial activity of the capsule, tablet and powder but our data is too limited to form a definitive conclusion. Since we had no information on the industrial procedures, nor on the phytogeographic origin of the propolis contained in the commercial products, we were unable to determine which of these possibilities was the most significant. On the other hand, the high activity of powdered propolis resin against only $B$ cereus (table II) indicates that this resin may have speciesspecific action.

The present findings indicate that the antibacterial activity, and perhaps other biological properties of propolis, could not be correlated with their resin concentration but mostly with their chemical composition, which can be variable according to the collection site (Tomas-Barberán et al, 1993) and the quality of the resin. Therefore the methodology used was effective in the evaluation of the quality of antibacterial activity from both propolis and commercial products containing propolis.

Resin quality and resin concentration can be used to have access to the in vitro activity of a given commercial product. This and the in vivo activity may be considered to establish the posology of each product. Currently resin quality and dosage are not specified in commercial products containing propolis from Brazil. 


\section{ACKNOWLEDGMENTS}

We thank Fundação Tropical de Pesquisa e Tecnologia André Tosello (Campinas, SP, Brazil), for supplying the microorganisms (CCT) utilized in this investigation. We are grateful to J Burgess for revision of the manuscript and to L Orlando Rosário for his technical assistance.

\section{Résumé - Propriétés antibactériennes} de la propolis et des produits renfermant de la propolis du Brésil. Des produits renfermant de la propolis disponibles dans le commerce au Brésil ont été analysés du point de vue de leur concentration en résine et de l'activité antibactérienne. Ils comprenaient dix extraits alcooliques (CE1 à CE10) et des produits du commerce sous forme solide. Les résines des produits solides ont été extraites à l'éthanol et nommées Etablette, E-capsule et E-poudre selon leur formulation. On a fait, en outre, des extraits de deux propolis brutes, nommés E-Pinus et E-Eucalyptus (propolis provenant de sites reboisés respectivement en Pinus sp et Eucalyptus sp). La concentration en résine a varié de 1,5 à 14,2\% (tableau I), alors que les étiquettes des produits du commerce annonçaient une teneur comprise entre 10 et $33 \%$. La détermination de la « concentration limite» (LC), c'est-à-dire la concentration minimale en résine ( $\mu \mathrm{g}$ de résine par $\mathrm{mL}$ du milieu de culture) qui inhibe complètement la croissance bactérienne, a servi à évaluer l'activité bactérienne (tableau II). Les valeurs de la LC ont montré que l'organisme le plus sensible était toujours Bacillus cereus, suivi par $B$ subtilis et Staphylococcus aureus. Certains produits, comme CEI0, ont présenté une concentration en résine élevée mais une faible activité bactérienne. Cela montre que des résines différentes ont des qualités différentes. La qualité de la résine dépend peut-être de son origine, puisque les deux préparations de propolis faites au laboratoire (E-Pinus et E-Eucalyptus) avaient une activité contre $S$ aureus et $B$ subtilis légèrement différente. La qualité de la résine peut être aussi influencée par le procédé de fabrication ou les conditions de stockage. La résine de la propolis en poudre avait une activité élevée contre $B$ cereus uniquement, ce qui montre que son action est spécifique à l'espèce. La méthode présentée ici peut être utilisée pour évaluer la concentration en résine et l'activité antibactérienne in vitro des produits du commerce renfermant de la propolis. Il faudrait prendre en compte ces deux caractéristiques, ainsi que l'activité in vivo, pour établir la posologie de chacun de ces produits.

propolis / contrôle qualité / activité antibactérienne / Staphylococcus aureus / bacillus subtilis / Bacillus cereus

\section{Zusammenfassung - Antibakterielle} Wirkung von Propolis und von propolishaltigen Produkten in Brasilien. Der Harzgehalt und die antibakterielle Aktivität von propolishaltigen Handelsprodukten aus Brasilien wurden untersucht. Die Proben setzten sich aus 10 Alkolholextrakten (CE 1 bis CE 10) und aus festen Substanzen zusammen. Aus den festen Handelsprodukten wurde das Harz mit Ethanol extrahiert, die Produkte wurden entsprechend als E-Tablette, E-Kapsel und E-Pulver bezeichnet. Zusätzlich wurden noch 2 andere rohe Propolisproben extrahiert und als E-Pinus (Propolis aus einer mit Pinus spec aufgeforsteten Region) und E-Eukalyptus (Propolis aus einer mit Eucaliptus spec aufgeforsteten Region) bezeichnet. Die Harzkonzentration variierte in allen Aufarbeitungen von 1,514,2\% (Tabelle I), obwohl auf den Etiketten der Handelsprodukte ein Harzgehalt von 10 - $33 \%$ angegeben war. Die Bewertung der bakteriziden Aktivität (Tabelle II) erfolgte durch die Bestimmung der ,limit concentration" (LC), also der geringsten Konzentration ( $\mu \mathrm{g}$ Harz per ml Kulturmedium), bei der eine totale Hemmung des Bakterienwachstums erfolgte. Die LC-Werte ergaben, daß Bacillus cereus immer der empfindlichste Organismus war, gefolgt von $B$ subtilis und Staphylococcus aureus. Einige 
der Produkte wie CE 10 hatte eine hohe Harzkonzentration, aber eine niedrige bakterizide Wirkung, wodurch eine unterschiedliche Qualität der verschiedenen Harze belegt wird. Die Harzqualität dürfte von seiner Herkunft abhängen, da die Propolis - Laborextrakte von E-Pinus und EEucalytus leicht unterschiedliche Aktivitäten gegenüber $S$ aureus und $B$ subtilis zeigten. Zusätzlich kann die Harzqualität auch durch den Herstellungsprozess oder die Art der Lagerung beeinflußt werden. Das Harz vom pulverisierten Propolis hatte nur gegen $B$ cereus eine hohe Aktivität, demnach ist dieses Harz artspezifisch wirksam.Die hier beschriebene Methode ist geeignet, die Harzkonzentration und Aktivität von Harz in vitro bei Handelsprodukten mit Propolis zu überpüfen. In Verbindung mit der in vivo Aktivität sollten diese Versuche die Möglichkeit eröffnen, eine Dosiologie für jedes dieser Produkte festzusetzen.

\section{Apis mellifera / Propolis / Harz / Qua- litätsprüfung /antibakterielle Wirkung / Staphylococcus aureus / Bacillus cereus / Bacillus subtilis}

\section{REFERENCES}

Ackermann TH (1991) Fast chromatographic study of propolis crudes. Food Chem 42, 135-138

Amoros M, Simões CMO, Girre L, Sauvager F, Cornier M (1992) Synergistic effect of flavones and flavonols against herpes simplex virus type 1 in cell culture. Comparison with the antiviral activity of propolis. $J$ Nat Prod 55, 12, 1732-1740

Dobowolski JW, Vohora SB, Sharma K, Shah SA, Naqvi SAH, Dandiya PC (1991) Antibacterial, antifungal, antiamoebic, antiinflammatory and antipyretic studies on propolis bee products. $I$ Ethnopharmacol 35, 77-82

Frenkel K, Wei H, Brimani R, Ye J, Zadunaisky VA, Huang M, Ferraro T, Conney AH, Grumberger D (1993) Inhibition of tumor promoter-mediated processes in mouse skin and bovine lens by caffeic acid phenethyl ester. Cancer Res 53, 1255-1261

Ghisalberti EL (1979) Propolis: a Review. Bee World $60,2,59-84$

Ginanneschi M, Acciani MC, Sertoli S, Bracci S (1989) Propolis allergy: synthesis and patch testing of $\gamma, \gamma-$ dimethylallyl caffeic acid ester and its O-methyl derivatives. Contact Dermatitis 21, 267-269

Grange JM, Davey RW (1990) Antibacterial properties of propolis. $J R$ Soc Med 83, 159-160

Haiji F, Fkih-Tetouani S (1993) Antimicrobial activity of twenty-one Eucalyptus essential oils. Fitoterapia $64,71-77$

Hausen BM, Wollenweber E, Senff H, Post B (1987a). Propolis allergy (I). Origin properties, usage and literature review. Contact Dermatitis 17, 163-170

Hausen BM, Wollenweber E, Senff H, Post B (1987b) Propolis allergy (II). The sensibilizing properties of 1,1-dimethylallyl caffeic acid ester. Contact Dermatitis 17, 171-177

Marcucci MC (1995) Propolis: Chemical composition, biological properties and therapeutic activity. Apidologie 26, 83-95

Scheller S, Szaflarski J, Tustanowski E, Nolewajka E, Stojka A (1977) Biological properties and clinical applications of propolis. VII. Investigation of the influence of ethanol extract of propolis (EEP) on cartilaginous regeneration. Arzneim-Forsch/Drug Res 27, 2138-2140

Scheller S, Gazda G, Krol W, Czuba Z, Zajuzz A, Gabys J, Shani J (1989) The ability of ethanolic extract of propolis to protect mice against gamma irradiation. Z Naturforsch 44c, 1049-1052

Singh Z (1972) Propolis collection and its use. Indian Bee J 34, 1/2, 11-19

Starzyk J, Scheller S, Szaflarski J, Moskwa M, Stojko A (1977) Biological properties and chemical application of propolis. II. Studies on the antiprotozoan activity of extract of propolis. Arzneim-Forsch/Drug Res 27, 1, 1198-1199

Stojko A, Scheller S, Szwarnowiecka I, Tustanowski J, Obuszko Z (1979) Biological properties and clinical applications of propolis. VIII. Experimental observation on the influence of ethanol extract of propolis (EEP) on the regeneration of bone tissue. Arzneim-Forsch/Drug Res 28, 35-37

Tomás-Barberán FA, Ferreres F, Garcia-Vigueera C, Tomás-Lorente F (1993). Flavonoids in honey of different geographical origin. $Z$ Lebensm-Unters Forsch 196, 38-44

Vanhaelen M, Vanhaelen-Fastré R (1979) Propolis-II. Identification par chromatographies haute-performance (liquide, gaz-liquide et sur couches minces) des constituants. Bioautographie des chromatogrammes des composés antibactériens. J Pharm Belg 34, 6, 317-328

Volpert R, Elster EF (1993) Biochemical activity of propolis extracts II. Photodynamic activities. $Z$ Naturforsch 48C, 858-862

Volpert R, Elstner EF (1996) Interactions of different extracts of propolis with leukocytes enzymes. Arz. nein-Forsch/Drug Res 46, 47-51

Waksmann SA, Reilly HC (1945) Agar-streak method for assaying antibiotic substances. Ind Eng Chem $17,556-558$ 